\title{
The Slow Sublime and 9/11: Insecurity and Fear in William Basinski's The Disintegration Loops
}

\author{
ELLIS JONES
}

I came across these big cases back in the storage room-The Land That Time Forgot, we used to call it-and I found all my old tape loops. By then I had a CD burner, and knowing what happens to old tapes, I started to archive the loops to digital. In the summer of 2001, in late July or August, I pulled this one loop out that I didn't remember at all, and put it on the machine [...] and I turned on the recorder and started recording. After about 15 minutes, I realized something was changing - and I looked, and I could see dust in the tape path on the ReVox that was playing the tape loop. I sat there watching the recorder, monitoring it as this thing over the length of a CD-R completely disintegrated in the most profoundly beautiful way. The sustains sort of fell away, and yet somehow the core of it stayed-the attack and the basic rhythm of the melody-hanging on desperately until the very end. I put the next one on, and it started doing it too. And that's when I realized I didn't need any countermelodies there; I just need to concentrate on what's happening and stay out of the way and make sure the recorder is on. So over a period of two long days, these six loops did their thing in their own way and in their own time, and just moved me so profoundly that I was just on the phone calling everybody: Get over here, you won't believe what happened! ${ }^{1}$

The process of artistic creation, if it can be so called, that William Basinski describes above is one you could forgive him for being tired of recounting. The story of the technological accident that brought about his career-defining The Disintegration Loops is one half of the "origin myth" that he has retold in countless interviews since the work's release, in four volumes, across 2002 and 2003. The other indispensable element in any media retelling is the work's relationship to the destruction of the World Trade Centre on September 11, 2001. Basinski apparently completed the work in New York City on the very morning of $9 / 11,{ }^{2}$ and has made explicit links between the piece and the event, both through interviews and through his choice of accompanying materials (cover art, video footage, liner notes, and so on). The piece has become recognized as a quasi-official elegy, through its performance at publicly funded memorial concerts and its upcoming induction into the National September 11 Memorial \& Museum. ${ }^{3}$

In this essay I aim to consider William Basinski's The Disintegration Loops as both an evocation of an event - the attack on the World Trade Center-often described in terms equatable to sublimity, and as a musical event that may be considered an evocation of sublimity in and of itself. The Disintegration Loops is by no means alone in having this dual relationship with sublimity, in which its subjective representation of an object becomes objectified in turn by the listener subject. Any art that is both about the sublime "moment of blockage" and also seeks to bring about that "blockage" in the mind of its

\footnotetext{
${ }^{1}$ William Basinksi, interview by Emilie Friedlander, "Interview: William Basinski," The Fader, http://www.thefader.com/2012/09/11/interview-william-basinski/.

${ }^{2}$ Ibid.

${ }^{3}$ Temporary Residence Ltd., accessed March 2, 2013, http://shop.temporaryresidence.com/trr194. 
audience, that seeks to both show and tell, is necessarily engaged in an attempt to reproduce meaning across different semiotic fields. ${ }^{4}$

I must acknowledge that my theorizing from hereon in relies on a resolutely "Western" reading of events that involves positioning America, or "the West" more generally at the front end of a subject-object relationship that to some extent depersonifies those responsible for the 9/11 attacks. In taking this perspective I do not mean to suggest that one could not equally position America as "object" or as Other but only that The Disintegration Loops is most usefully considered as a product of American culture and the context in which it was created and received, and in which this essay therefore situates itself.

Most theorists find the sublime moment to require the subject to be at least one step removed from the awful (i.e., awe-full) or terrifying object. Edmund Burke, for example, suggests that the sublime presents itself "when we have an idea of pain and danger, without actually being in such circumstances." 5 Thus it is an inherent thrill of self-preservation that is manifested in the observation of tragedy. ${ }^{6}$ In music it is often unclear whether we are witnessing the object (be that composer, performer, or the personified work) in a situation in which we would not wish to find ourselves, thus placing us as the witness, or whether the object is located beside us as a fellow witness, an onlooker experiencing sublimity. Do we to some extent become a protagonist in the musical narrative? In fact, music's ability to transcend space and place (allowing us to be, as Simon Frith writes, "only where the music takes us"7) ruptures such notions of stable identity, allowing performer and listener to be simultaneously any combination of protagonist and witness. The video art that accompanies Disintegration Loops, however, seems to make its intended "witness" position clear. The loop "dlp1.1" plays, whilst we see a single, static shot of the New York City skyline on the evening of September 11, 2001. Over the course of one hour, the smoke slowly moves across the darkening sky as evening turns into night.

\section{http://youtu.be/KaMT6GkzZwg}

Figure 1: Audio of dlp1.1

In his landmark 1976 text The Romantic Sublime, Thomas Weiskel writes that the sublime is "a major analogy, [...] a stunning metaphor." ${ }^{8}$ In short, what we say about the sublime is not an adequate description of what we feel whilst experiencing it. One might also make the same claim for music, raising the issue of how we might accurately draw comparison between three semiotic fields (music, language, mind) without simply assuming that a parallel in language means a parallel in experience. The term "annihilation," for example, might with equal aptitude describe the gradual reduction of musical material in Disintegration Loops, the sense of loss-of-self associated with sublimity, and the destruction wrought in the September 11 terrorist attacks. But this does not mean that we can claim with any validity that these experiences are similar-in fact, to do so is to cheapen and degrade their respective properties. My aim in this essay is to suggest connections between the event of $9 / 11$ and the musical event of The Disintegration

\footnotetext{
${ }^{4}$ Neil Hertz, "The Notion of Blockage in the Literature of the Sublime," The End of the Line: Essays on Psychoanalysis and the Sublime (New York: Columbia University Press, 1985), 41.

${ }^{5}$ Edmund Burke, A Philosophical Enquiry into the Origin of our Ideas of the Sublime and Beautiful (New York: Dover, 2008), 35 .

6 "No man is so strangely wicked as to wish to see [London] destroyed by a conflagration or an earthquake [...] But suppose such a fatal accident to have happened, what numbers from all parts would crowd to behold the ruins, and amongst them many who would have been content never to have seen London in its glory?" Ibid., 32.

${ }^{7}$ Simon Frith, Performing Rites: On the Value of Popular Music (Cambridge, MA: Harvard University Press, 1996$), 125$.

${ }^{8}$ Thomas Weiskel, The Romantic Sublime (Baltimore: Johns Hopkins University Press, 1986), 4.
} 
Loops at a level beyond metaphor or linguistic coincidence, through analysis based on the Kantian sublime, as expanded by Lyotard and Weiskel to extend to human-made objects, and therefore art. I hope to show that certain similarities in the manner in which sublimation is brought about by the two events might go some way to explaining the critical consensus that holds The Disintegration Loops to be an appropriate musical response to the event that it commemorates.

This exploration of gradual change is not unique to Basinski's loops-it is possible to sketch a lineage of contemporary works, by the likes of Steve Reich and Gavin Bryars, that have used tape loops in order to play with similar ideas of repetition and slowness. Bryars's composition The Sinking of the Titanic (an open composition, begun in 1969 and first recorded in 1975) ${ }^{9}$ seems particularly congruous, as it addresses a similarly devastating loss of life (albeit at a greater historical distance) using comparable techniques. Just as The Disintegration Loops seems to exist in that terrible, post-impact period of confusion and struggle, so The Sinking of the Titanic is consciously positioned in the long, desperate hours after the ship hit the iceberg. But whereas the disintegration of Basinski's tape loops implies decay and destruction, Bryars's slow, plaintive strings imagine an impossible feat of survival, as the band plays on even as they are submerged beneath the sea. In both pieces however, slowness becomes a process of, if not quite immortalization, at least extension of life, by slowing time and elongating memory.

Weiskel suggests that sublimity, at its simplest, "comes down to the claim that the failure to understand something has the very highest meaning." $\mathrm{He}$ therefore argues that sublimity requires a "credible god-term" in order to find meaning in that miscommunication. ${ }^{11}$ The Romantic poets found this "god-term" in nature, Kant found it in the triumph of reason, and Hitler and his followers located it in the mythologized Volk. It is worth considering whether, in the context of Basinski's loops (and indeed Reich's and Bryars's work as well), this god-term might relate in some way to the creative and destructive potential of technology, and the almighty power of technocapitalist progress. Weiskel argues, "we have lost the obsession, so fundamental to the Romantic sublime, with natural infinitude. We live once again in a finite natural world whose limits are beginning to press against us and may well crush our children." ${ }^{12}$ Advances in technology appear to offer new kinds of infinitude, but as Basinski's work illustrates, technology also meets physical and temporal limits.

With hindsight, it has become easy to consider the months and years before September 11, 2001, as a period of somnambulant complacency in which, according to Jean Baudrillard, "events were 'on strike."”13 Whilst the apparent flawless normalcy of this period is no doubt a simplification, we might usefully consider this state as the first of Weiskel's three phases of the sublime experience, "normal perception," in which "the mind is in a determinate relation to the object, and this relation is habitual, more or less unconscious [...] and harmonious." "For Slavoj Žižek, whilst this normal perception was in fact something like "a staged fake," or a "virtual reality" that excluded elements of the Real, it nonetheless constituted "our reality":

One should therefore turn around the standard reading according to which, the WTC explosions were the intrusion of the Real which shattered our illusory Sphere: quite on the

\footnotetext{
${ }^{9}$ Paul Morley, “Gavin Bryars's Sinking of the Titantic," Sinfini Music, December 20, 2012.

${ }^{10}$ The Romantic Sublime, 34.

${ }^{11}$ Ibid., 36.

${ }^{12}$ Ibid., 6. For more, see Christopher Hitt, "Towards an Ecological Sublime," in "Ecocriticism," special issue of New Literary History 30, no. 3: 603-23. http://dx.doi.org/10.1353/nlh.1999.0037

${ }^{13}$ Jean Baudrillard, "The Spirit Of Terrorism," in The Spirit Of Terrorism (London: Verso, 2002), 3.

${ }^{14}$ The Romantic Sublime, 23.
} 
contrary [...] It is not that reality entered our image: the image entered and shattered our reality (i.e., the symbolic coordinates which determine what we experience as reality) ${ }^{15}$

Žižek here is unusually pragmatic. It is almost irrelevant whether the Real invaded the image, or vice versa-the important aspect is that, for many people, the perception and feeling of reality was disrupted by an event that seemed to come from outside of its borders, and therefore from beyond the limits of comprehension. Ty Solomon describes the way in which this lack of comprehension led to an inability to react emotionally:

'Unspeakable' and 'unbelievable' seemed to be the only signifiers available to try and symbolise what had happened. Familiar discursive tropes no longer seemed adequate to express what was presumably experienced. With no such resources available to make sense of what had happened, no definable emotional response was yet possible. As one person indicated, 'At first I wasn't angry, because I couldn't believe it was happening. ${ }^{16}$

Here we see the second phase of the sublime, in which the relationship between mind and object has, in Weiskel's terms, "become radically indeterminate" and for which "surprise or astonishment is the affective correlative." 17 For Kant, the root cause of this indeterminacy, for which "the imagination fruitlessly expands its entire capacity for comprehension," is "magnitude." 18 The magnitude in this instance resides not primarily in the visual spectacle-which was, as Žižek argues, only a replication of the destruction that America had "fantasized about" in countless Hollywood movies_but in the size of the rupture in "our reality" caused by the symbolic destruction of the "center of virtual capitalism." 19

Weiskel's three-phase sublime offers a conventional narrative of there-and-back-again, via the dramatic moment of a lesson learned; the obstacle is surmounted through character development. In the third stage of the sublime, "the mind recovers the balance of outer and inner by constituting a fresh relation between itself and the object." "The new relation," writes Weiskel, "has a 'meta' character, which distinguishes it from the homologous relation of habitual perception." ${ }^{20}$ This appears to rely on a certain solidity of the subject, in order that in the sublime exchange ("a series of changes in the distribution of energy within a constant field") might result, via some swift mental bookkeeping ("roughly calculating gain and loss"), in a new determinate relationship between subject and object. ${ }^{21}$

With this in mind, we might consider whether the subject's response to $9 / 11$ called merely for the reconstitution of a single subject-object relationship, or for a countless number of new transactions. What if the disruption of the second phase of the sublime called for the re-evaluation of so many existing relationships as to effectively draw in to question the existence of the subject itself? If we consider "our reality" as a constitution of all our existing subject-object relationships, then it stands to reason that after the rupture of $9 / 11$, the idea of return to a changed but essentially recognizable "home" might seem impossible.

Solomon states that, in the immediate aftermath of $9 / 11$, "conventional emotional signifiers were not up to the task of giving contour to the experience. Only after the spread of official and other cultural

\footnotetext{
${ }^{15}$ Slavoj Žižek, "Welcome to the Desert of the Real: Reflections on WTC, Third Version," The Symptom no. 2 (2002), http://lacan.com/desertsymf.htm.

${ }^{16}$ Ty Solomon, “I Wasn't Angry Because I Couldn't Believe It Was Happening': Affect and Discourse in Responses to 9/11,” Review of International Studies 38, no. 4 (2012): 925. http://dx.doi.org/10.1017/S0260210511000519

${ }^{17}$ The Romantic Sublime, 23-4.

${ }^{18}$ Immanuel Kant, Critique of the Power of Judgement. (Cambridge: Cambridge University Press, 2000$), 139$.

19 "Welcome to the Desert of the Real." http://dx.doi.org/10.1017/CBO9780511804656

${ }^{20}$ The Romantic Sublime, 24.

${ }^{21}$ Ibid., 25.
} 
discourses did emotional responses begin to take shape."22 In other words, it was the re-establishment of other subject-object relationships, or the realization that these relationships were not affected, that allowed people to address the root cause, and work towards a meta-relationship with the event itself. This is the context in which The Disintegration Loops was first released, becoming part of the cultural discourse on 9/11 that aided the possibility of emotional reaction, and part of the "fresh relation" between subject and object.

It is perhaps worth noting that The Disintegration Loops was in fact composed and completed before the attacks on the World Trade Center, and therefore in terms of compositional choices, we cannot say that William Basinski was influenced by September $11 .^{23}$ However, the composer certainly made a concerted effort, in the overall presentation of the work, to associate his music with that day's events. The four volumes of The Disintegration Loops were released on CDs with cover art featuring stills from a home video recorded by Basinski on the evening of 9/11, capturing the last hour of daylight over the New York City skyline. Basinski also released a DVD featuring this single, one-hour shot, soundtracked by his first disintegration loop (“dlp 1.1”). For Basinski, it was experiencing this combination of video and audio that revealed to him the purpose of his work:

The next morning when I looked at it, I put on Disintegration Loop 1.1 and just sat there and lined it up, and it was just so moving; I knew it was an elegy. It reminded me of Jacqueline Kennedy, who wore that Chanel suit for a whole day with her husband's blood on it, and they were trying desperately to get her to change, and she said, No... I want them to see what they have done to Jack. ${ }^{24}$

Basinski's rather graphic analogy here suggests that his work functions as a brutal reminder, an inescapable vision of destruction. But could we really argue, in the wake of $9 / 11$, that we were not presented with enough images of the burning towers? Surely not-the problem is, according to Žižek, that the overexposure to such similar images in fiction have left us unable to comprehend their "Real" meaning. ${ }^{25}$ For Baudrillard, the repeated broadcasts of the same footage of 9/11 "serve to multiply it to infinity and, at the same time, they are a diversion and a neutralization"- the more we see the events, the less comprehensible they become. ${ }^{26}$ If Jackie Kennedy's bloodstained suit was an attempt to reconnect the symbolic death of the president with the actual death of her husband, Basinski's music is perhaps the reverse-an attempt to reconnect the visceral images of death with the symbolic meaning of the event. Basinski is claiming that to listen to The Disintegration Loops is to "see what they have done" with a greater clarity than can be achieved by actually seeing the destruction, the planes, and the bodies. Here, Lyotard's sublime moment of "is it happening?," the search for the Real through avant-garde art, also provides the moment of did it happen?, as a step towards establishing a determinate meta-relationship between subject and object, through art. $^{27}$

\footnotetext{
22 “Affect and Discourse in Responses to 9/11," 925.

${ }^{23}$ In this respect it is perhaps an example of what Ed Park, writing on the impact of 9/11, labels "clairvoyant art"-a work that with hindsight suddenly appears particularly profound or prophetic. "Reflections on That Dreadful Tuesday," New York Times, September 6, 2008, http://www.nytimes.com/2008/09/07/nyregion/thecity/07fati.html.

${ }^{24}$ Friedlander, "Interview: William Basinski."

25 "Welcome to the Desert of the Real."

26 "The Spirit of Terrorism," 26.

${ }^{27}$ Jean-François Lyotard, "The Sublime and the Avant-Garde," in The Inhuman: Reflections on Time (Stanford: Stanford University Press, 1988), 99.
} 

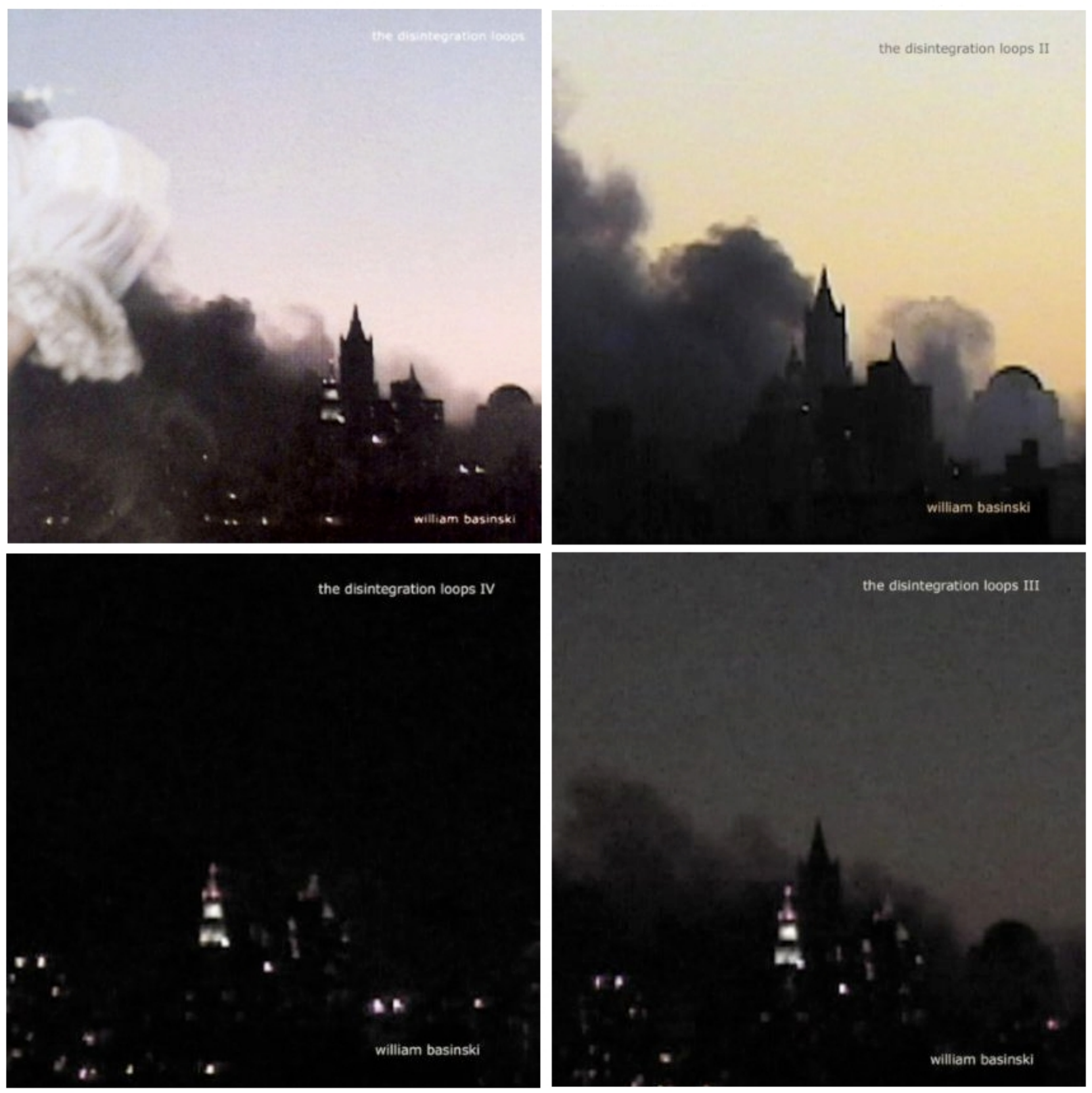

Figure 2: Album art for The Disintegration Loops, Volumes I-IV.

Kant's sublime is characterized by the entry of a new power ("a capacity that is superior to great obstacles"), which is then recognized as "a power that has no dominion over us," thus confirming the subject's superiority. ${ }^{28}$ The basis for superiority over the Other (in Kant's case, nature and the nonhuman world) "is found in our own mind," as the faculty of reason. It is reason that allows us to "recognize our physical powerlessness," whilst also recognizing that "the humanity in our person remains undemeaned." 29 Thus, this process not only draws a binary distinction between the opposing powers of self and other, but also requires the creation of a noumenal realm over which the self has total dominion, beyond the consideration of any possibility of physical threat. Žižek writes:

\footnotetext{
${ }^{28}$ Kant, Critique of the Power of Judgement, 143.

${ }^{29}$ Ibid., 145.
} 
So what about the phrase which reverberates everywhere, 'Nothing will be the same after September 11'? Significantly, this phrase is never further elaborated-it is just an empty gesture of saying something 'deep' without really knowing what we want to say. So our first reaction to it should be: Really? Is it, rather, not that the only thing that effectively changed was that America was forced to realize the kind of world it was part of $?^{30}$

The suggestion is that "America," pre-9/11, had overestimated its power to the extent of forgetting the Other entirely, thus considering itself an infinite totality, occupying a borderless domain.

In The Disintegration Loops, we are initially presented with what appears to be an infinite totality (the loop on repeat), which is then disturbed not by the addition or subtraction of material, but by the lack of anything - the sound of destruction itself. But silence is not nothing; it is a competing power. It occupies the same "dominion" as sound-the presence of silence prevents the presence of sound, and vice versa. Even as the domain itself expands, with the passing of musical time, the process can never be anything other than dialectical.

Žižek posits that in order to understand 9/11, one must appreciate that the terrorist threat did not come out of the blue. He implores, "in this pure Outside, we should recognize the distilled version of our own essence. For the last five centuries, the (relative) prosperity and peace of the 'civilized' West was bought by the export of ruthless violence and destruction to the 'barbarian' Outside." ${ }^{11}$ Baudrillard writes of the twin towers "committing suicide," claiming that the symbolic power of the World Trade Center "was party to its own destruction."32

Whilst in both Žižek and Baudrillard there is a distasteful sense of schadenfreude in the posthoc, told-you-so assertion that American "had it coming," there is some undeniable logic to their statements. Even if we question the directly dialectical link between global capitalism and global terrorism, we must still acknowledge that there is some system of cause-and-effect that makes it possible to see $9 / 11$ as something more cyclical and self-destructive than the intrusion of one world into another. The act of creation always contains the possibility of destruction-Weiskel's metaphor of economic exchange would suggest that any act of destruction, even at the level of the symbolic, must be only a reconfiguration of a fixed amount of material, and therefore in some sense a creation.

This is the double surprise of both 9/11 and The Disintegration Loops-something arrives to disrupt the totality, which is then discovered to have been part of that totality all along. One might see this as comparable to Kant's "humility," a "sublime state of mind, that of voluntarily subjecting oneself to the pain of self-reproach in order gradually to eliminate the causes of it." ${ }^{33}$ Conspiracy theories aside, it is certainly a stretch to consider 9/11 as a "voluntary" act from a Western perspective (Baudrillard's suggestion that the twin towers committed "suicide" is difficult to take at face value), but the cultural discourse that followed certainly touched on areas of "self-reproach." A less congratulatory reading might see the so-called "War on Terror" as the inevitable end result of this attempt to "eliminate" unsavory elements of the self.

This kind of theorizing raises the question of whether it is entirely appropriate to discuss 9/11 in terms of "sublimity," when the term has largely been, from Longinus through to Lyotard, associated with aesthetics rather than actual disaster. For Kant, the sublime was to be found only in the transcendental

\footnotetext{
30 "Welcome to the Desert of the Real."

${ }^{31}$ Ibid.

${ }^{32}$ Jean Baudrillard, "Requiem For The Twin Towers" in The Spirit Of Terrorism (London: Verso, 2002$), 45$.

${ }^{33}$ Kant, Critique of the Power of Judgement, 147.
} 
design of nature, which offers immanence unmatched by manmade spectacle. Weiskel derides this as an "inadequate" view, and suggests that we may substitute for natural phenomenon "any object (a line of poetry, for example)," provided that "the attempt to represent it determines the mind to regard its inability to grasp wholly the object as a symbol of the mind's relation to a transcendent order." ${ }^{24}$ Notably, this roomy definition does not rule out the possibility of sublimity arising from immoral or unethical acts. Karlheinz Stockhausen was roundly castigated for labeling 9/11 "the greatest work of art that is possible in the whole cosmos," in which "people practice like crazy for 10 years, totally fanatically, for a concert, and then die." 35 In a similar vein, British visual artist Damien Hirst pronounced that "the thing about 9/11 is that it's kind of an artwork in its own right. It was wicked, but it was devised in this way for this kind of impact. It was devised visually." ${ }^{36}$ Hirst's comments were met with far less opprobrium than Stockhausen's, perhaps because there is undoubtedly some truth in his statement. Whilst not an "artwork" in any sense, 9/11 was certainly intended to create an image that would be globally recognized as shocking - the destruction of a hugely symbolic American landmark. ${ }^{37}$ Žižek's contention is not that 9/11 was a work of art, but that a Western audience, responding to 9/11 at the time, was unable to tell the difference between fiction and reality-Stockhausen's wild claims are perhaps, by this logic, a typical Western response.

Basinski's disintegrating loops use a variety of tonal and textural material, and a great deal of their power arises from the tonal and rhythmic ambiguity present in this source material, which was apparently largely recorded from radio broadcasts in the 1980s. ${ }^{38}$ The harmonic confusion is caused by a combination of the recording format itself (the tape hiss either obscuring or creating mysterious overtones) and by the reverb effect applied to the loops. Edmund Burke notes that terror, and thus sublimity, often stems from "low tremulous, intermitting sound," creating a "fearful anxiety concerning their causes." version of "dlp1.1" arranged for live performance these ambiguities are replaced by a single clear melodic phrase (which, to my ears, is not the most prominent melody in the original loop) and a tight, six-beat rhythm (cordoned off by militaristic snare drum rolls) in place of the lolloping, lopsided rhythm of the original. The effect of this "tightening" is that the jarring effect of repetition is lost - the piece carries a much more standard musical "flow" in which the end of each phrase meets the beginning of the next with formal cordiality, and the sense of anxiety and uncertainty is greatly reduced. ${ }^{40}$

\footnotetext{
${ }^{34}$ Weiskel, The Romantic Sublime, 23.

${ }^{35}$ Anthony Tommasini, “The Devil Made Him Do It," New York Times, September 30, 2001, http://www.nytimes.com/2001/09/30/arts/music-the-devil-made-him-do-it.html.

${ }^{36}$ Rebecca Allison, "9/11 Wicked but a Work of Art, says Damien Hirst," The Guardian, September 11, 2002, http://www.theguardian.com/uk/2002/sep/11/arts.september11.

${ }^{37}$ J. Martin Daughtry's introduction to Music in the Post-9/11 World concurs that it is not "the size of the calamity, measured in innocent dead" that renders $9 / 11$ "so momentous" but "the globally recognized symbolic dimension to the attacks on the world's sole superpower.” Jonathan Ritter and J. Martin Daughtry, eds., Music in the Post 9/11 World (New York: Routledge, 2007), xxii.

38 "I'd tune the radio in to this station, wait until something really string-y came up, either an introduction or an end or an interlude on one of these muzak numbers and I would grab a bit like a measure. Then I'd slow it down and see what I'd got. [...] So I found that these were the kind of textures I was interested in working with, making a tapestry with them, creating cyclic rhythms with them. And the fact that this stuff was leaking out of the airwaves, meant it felt like I was creating something out of nothing. It was one wild, mad experiment.” Basinski, interviewed by John Doran, “Time Becomes A Loop: William Basinski Interviewed," The Quietus, November 15, 2012.

${ }^{39}$ Burke, Philosophical Enquiry, 62.

${ }^{40}$ Burke comes close to addressing this when discussing "suddenness"-consistency of rhythm is less terrifying than the uncertainty of a jolting starting and stopping (such as "a single stroke on a drum, repeated with pauses," or "the successive firing of a cannon at a distance"). Ibid., 62.
} 
http://youtu.be/9U9F1Jmndt0

Figure 3: audio of The Disintegration Loops, live

There is substantial variation in the manner in which the loops decay across the four volumes of Basinski's work-some take an hour to be steadily whittled down, others lose content quickly, in noticeable chunks, before apparently regaining stability—but in each case, the fade-out signaling the end of each track comes before the complete disintegration of the loop, and before the totality of sound is transformed into the totality of silence. In preventing his loops from ever reaching the totality of silence, Basinski highlights the sublimity of the revelation of scale. The first repetitions of the loops are identical to each other, and in their comparability only to themselves offer no sense of "vastness." Is it possible for one loop to be, in Kant's terms, "a magnitude equal only to itself," when it is preceded and followed by its identical twin? ${ }^{41}$

It is only with the gradual removal of material that a sense of perspective is generated, as the potential for infinite division simultaneously highlights the infinite size of what is being divided. Lyotard states that we should not conclude that the world is "infinite in intensive magnitude," but that "what is infinite is the progression in the decomposition into parts." ${ }^{42}$ Edmund Burke addresses precisely this effect as a cause of sublimity:

when we attend to the infinite divisibility of matter $[\ldots]$, when we push our discoveries downward $[\ldots]$ we become amazed and confounded at the wonders of minuteness; nor can we distinguish in its effect this extreme of littleness from the vast itself. For division must be infinite as well as addition; because the idea of a perfect unity can no more be arrived at, than that of a complete whole to which nothing may be added. ${ }^{43}$

For Baudrillard, the twin towers signaled "a halt to verticality," their very twin-ness acting as a "tautology of form" that prevented a true comprehension of scale. ${ }^{44}$ It is only with their destruction that they reveal their true sublimity, through their incomparability:

No one who knew them can cease imagining them and the imprint they made on the skyline from all points of the city. Their end in material space has borne them off into a definitive imaginary space. By the grace of terrorism, the World Trade Center has become the world's most beautiful building — the eighth wonder of the world! $!^{45}$

Here, the physical destruction of the twin towers has resulted in a symbolic elevation: "they, which were the symbol of omnipotence, have become, by their absence, the symbol of the possible disappearance of that omnipotence." 46

For many theorists of the sublime, sublimity can only be experienced with a requisite distance from danger ${ }^{47}$ - a guarantee that one is a witness to, rather than a victim of the powerful force at hand. In the aftermath of 9/11, an accurate measurement of this distance seemed impossible to calculate. Žižek is cynical in his description of the resultant paranoia:

\footnotetext{
${ }^{41}$ Kant, Critique of the Power of Judgement, 134.

${ }^{42}$ Jean-François Lyotard, Lessons on the Analytic of the Sublime (Stanford: Stanford University Press, 1994$), 95$.

${ }^{43}$ Burke, Philosophical Enquiry, 53.

${ }^{44}$ Baudrillard, "Requiem for the Twin Towers," 42.

${ }^{45}$ Ibid., 48.

${ }^{46}$ Ibid., 44.

47 "But the sight of them [natural dangers, e.g., cliffs, thunderstorms] only becomes all the more attractive the more fearful it is, as long as we find ourselves in safety." Kant, Critique of the Power of Judgement, 144.
} 
when a New Yorker commented on how, after the bombings, one can no longer walk safely on the city's streets, the irony of it was that, well before the bombings, the streets of New York were well-known for the dangers of being attacked [...] if anything, the bombings gave rise to a new sense of solidarity. ${ }^{48}$

However, this was not just about a fear for one's own physical life, but a fear that normality had not been resumed, that the reality of before was not the reality of now. The message of The Disintegration Loops is not that things will forever be the same, but that change occurs in a manner that is ultimately comprehensible, and that is in keeping with the laws of cause and effect. Basinski's work offers a step-bystep journey between then and now, traveled in such a way as to make distinguishable the potentially infinite moments of transition between the two states. If the moment of breakdown in the second phase of the sublime can be seen as the sudden replacement of one totality by another, apparently from nowhere, The Disintegration Loops slows down this process in order to show the breaking of relationships that might eventually create this state, and in so doing shows how they may be reconstituted. Total paradigm shifts are replaced by concepts of scale, flux, and infinite movement within a totality. With this fluidity, however, comes a new and perhaps more inescapable sense of uncertainty. As Burke writes: "A light now appearing, and now leaving us, and so off and on, is even more terrible than total darkness; and a sort of uncertain sounds are, when the necessary dispositions occur, more alarming than a total silence."49

\section{Bibliography}

Allison, Rebecca. "9/11 Wicked but a Work of Art, Says Damien Hirst." The Guardian. September 11, 2002. http://www.theguardian.com/uk/2002/sep/11/arts.september11.

Baudrillard, Jean. “The Spirit Of Terrorism.” In The Spirit Of Terrorism, 1-34. London: Verso, 2002.

—_. "Requiem For The Twin Towers." In The Spirit Of Terrorism.

Burke, Edmund. A Philosophical Enquiry into the Origin of our Ideas of the Sublime and Beautiful. New York: Dover, 2008.

Doran, John. “Time Becomes aLoop: William Basinski Interviewed.” The Quietus, November 15, 2012. http://thequietus.com/articles/10680-william-basinski-disintegration-loops-interview.

Hertz, Neil. "The Notion of Blockage in the Literature of the Sublime." In The End of the Line: Essays on Psychoanalysis and the Sublime. New York: Columbia University Press, 1985.

Hitt, Christopher. "Towards an Ecological Sublime." In "Ecocriticism," special issue, New Literary History 30, no. 3 (1999): 603-23. http://dx.doi.org/10.1353/nlh.1999.0037

Friedlander, Emilie. "Interview: William Basinski.” The Fader, September 11, 2012. http://www.thefader.com/2012/09/11/interview-william-basinski.

Frith, Simon. Performing Rites: On the Value of Popular Music. Cambridge, MA: Harvard University Press, 1996.

Kant, Immanuel. Critique of the Power of Judgement. Cambridge: Cambridge University Press, 2000. http://dx.doi.org/10.1017/CBO9780511804656

${ }^{48}$ Žižek, "Welcome to the Desert of the Real."

${ }^{49}$ Burke, Philsophical Enquiry, 62. 
Lyotard, Jean-François. "The Sublime and the Avant-Garde." In The Inhuman: Reflections on Time, 89107. Stanford: Stanford University Press, 1988.

- Lessons on the Analytic of the Sublime. Stanford: Stanford University Press, 1994.

Morley, Paul. "Gavin Bryars's Sinking of the Titantic.” Sinfini Music, December 20, 2012. http://sinfinimusic.com/uk/features/series/paul- morley/002-the-sinking-of-the-titanic.

Park, Ed. "Reflections on That Dreadful Tuesday." New York Times, September 6, 2008. http://www.nytimes.com/2008/09/07/nyregion/thecity/07fati.html.

Ritter, Jonathan, and J. Martin Daughtry, eds. Music in the Post 9/11 World. New York: Routledge, 2007.

Solomon, Ty. “I Wasn’t Angry Because I Couldn't Believe It Was Happening': Affect and Discourse in Responses to 9/11.” Review of International Studies 38, no. 4 (2012): 907-28. http://dx.doi.org/10.1017/S0260210511000519

Tommasini, Anthony. “The Devil Made Him Do It.” New York Times, September 30, 2001. http://www.nytimes.com/2001/09/30/arts/music-the-devil-made-him-do-it.html.

Weiskel, Thomas. The Romantic Sublime. Baltimore: Johns Hopkins University Press, 1986.

Žižek, Slavoj. "Welcome to the Desert of the Real: Reflections on WTC, Third Version." The Symptom no. 2 (2002). http://lacan.com/desertsymf.htm. 